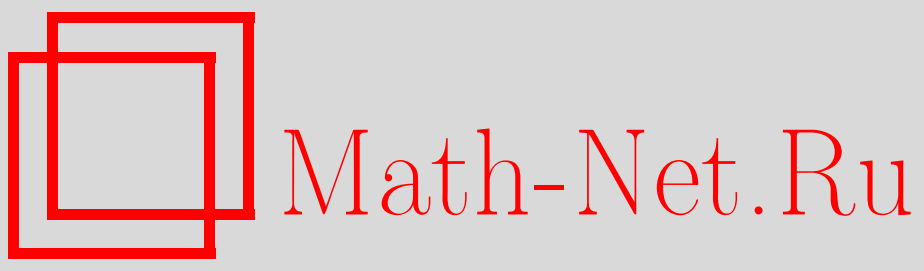

Вячеслав Васильевич Сазонов (к 60-летию со дня рождения), Теория вероятн. и ее примен., 1996, том 41, выпуск 2, 478

DOI: https://doi.org/10.4213/tvp2964

Использование Общероссийского математического портала Math-Net.Ru подразумевает, что вы прочитали и согласны с пользовательским соглашением http://www . mathnet.ru/rus/agreement

Параметры загрузки:

IP : 107.22 .136 .117

26 апреля 2023 г., 14:53:01

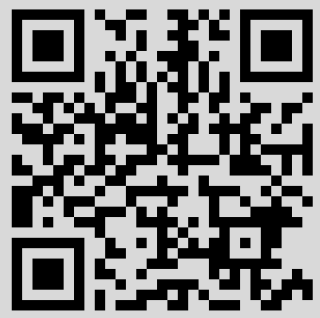


25 августа 1995 года исполиилось 60 лет члену редколлеаии журнала «Теория вероятностей и ее применения》, доктору физико-математических наук, профессору, Лауреату Государственной премии СССР

\section{Вячеславу Васильевичу Сазонову.}

Редахчиониая коллегия журнала «Теория вероятностей и ее применения》 поздравляет юбиляра, с именем которого сөязаны выдающиеся достижения в области теории вероятностей и в подготовке научных кадров. 